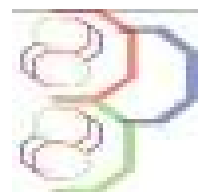

Journal of Applied Biosciences 64:4867 - 4875

ISSN 1997-5902

\title{
Heavy metal and associated antibiotic resistance of fecal coliforms, fecal streptococci and pathogens isolated from wastewaters of abattoirs in Nairobi, Kenya
}

\author{
Nyamboya Rosemary Atieno, Okemo Paul Owuor* and Ombori Omwoyo \\ Department of Plant and Microbial Sciences, Kenyatta University, P.O Box 43844-00100, Nairobi, Kenya \\ *Corresponding author, email address: paulokemo@gmail.com, Tel: +254722942072
}

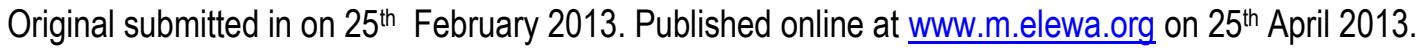

http://dx.doi.org/10.4314/jab.v64i1.88476

\begin{abstract}
Objective: The pollution of the environment with toxic heavy metals is increasing globally with industrial progress. Microorganisms can be good bio-accumulators of particulate and soluble forms of heavy metals and subsequently resist antibiotics. The present study aimed at assessing the resistance pattern to multiple heavy metals by wastewater bacteria and associated antibiotic resistance.

Methodology and results: Standard microbiological methods were used to isolate fecal streptococci, fecal coliforms, Vibrio and Salmonella species from raw animal wastewaters and sludge samples obtained from three abattoirs around Nairobi city. A total of 30 samples were collected. Agar diffusion and tube dilution methods were used to assess the heavy metal resistance while sensitivity to antibiotics was determined by the agar diffusion method. From the 40 isolates obtained, 27 showed multiple resistance to heavy metals. Resistance pattern was as follows; $\mathrm{Hg} 9$ (33.3\%), Co 11 (40.7\%), Cu 18 (66.7\%), Zn 19 (70.4\%), Pb 21 $(77.8 \%)$, and Ni $24(88.9 \%)$. Out of the 27 resistant strains, $5(18.5 \%)$ showed resistance to 5 different metal ions and only $1(3.7 \%)$ showed resistance to two different metal ions. With each of the six metals tested, there was a tendency towards a high frequency of resistance among the isolates to lincomycin (77.8\%), tetracycline $(70.4 \%)$ and ampicillin (66.7\%).

Conclusion and application of findings: In the present study, heavy metal resistance associated with multiple drug resistance was detected in the bacterial isolates from the wastewater and sludge of the cattle, sheep and goat abattoirs. The high degree of resistance to common antibiotics could be attributed to the contamination of the wastewaters and sludge with heavy metals possibly from animal feeds or drinking waters, leading to co-selection of both metal tolerant and antibiotic resistant microbial species. This requires intervention measures to curb the potential health hazard that heavy metal pollution pose in the environment. The identified heavy metal resistant bacteria could be useful for bioremediation of heavy metals contaminated sewage and wastewaters, but the coupled antibiotic resistance is a worrying phenomenon.
\end{abstract}

Keywords: Heavy metal resistant bacteria, antibiotic resistance, wastewaters, sludge, animals

\section{INTRODUCTION}

The introduction of different forms of heavy metals to the environment can lead to genetic structure modification and changes in microbial communities function. Heavy metals are essential micronutrients for bacterial growth and enzymatic activities; however they are toxic at elevated concentrations 
due to binding to DNA and enzymes and increased production of oxygen radicals through the Fenton reaction (Lopez-Maury et al., 2002). Trace metals are significant contaminants in many aquatic systems, partly from anthropogenic sources such as industrial and mining inputs. A microorganism's expression of a novel gene that codes for drug resistance in remote communities can have global implications. After the introduction of resistant organisms into a population, dissemination becomes rapid (Wenzel and Edmond, 2000). In the last decade many studies have shown that antibiotic resistant bacterial strains may arise in the environment through cross- or co-resistance to metals or resistance pathway co-regulation (Akinbowale et al., 2007). The interaction between heavy metals and antibiotic resistance are of three types: heavy metals interaction with antibiotic compounds, heavy metals interaction with antibiotic resistance genes or even their products and heavy metal interaction with bacterial

\section{MATERIALS AND METHODS}

Sampling site: The study focused on 3 abattoirs in Nairobi's Eastland area that are a representative of most abattoirs in the city. These included one cattle abattoir in Kayole, one sheep and one goats' abattoirs both in Kiamaiko. These abattoirs were selected because they are the largest cattle, sheep and goat abattoirs in Nairobi.

Sample collection and preparation: A total of thirty $100 \mathrm{~mL}$ samples of sludge and raw animal wastewater were collected from the three slaughterhouses in Nairobi County. Eighteen samples of wastewaters ( 6 samples of goat, sheep and cattle wastewaters each) and twelve samples of sludge (6 samples of cattle sludge and a mixture of goat and sheep sludge each) were obtained from all the three slaughterhouses. Samples were collected three times between 9 and 10 o'clock in the morning in the month of March 2012 and April 2012 in sterile $200 \mathrm{~mL}$ glass bottles and were transported to Kenyatta University laboratory in an ice cooler box for analysis. Wastewater samples that were not analyzed within four hours were stored at a temperature of $4{ }^{\circ} \mathrm{C}$. All samples were analyzed within $24 \mathrm{~h}$.

Isolation and identification of bacterial isolates: Standard microbiological methods were used to isolate fecal coliforms (FC), fecal streptococci (FS), Vibrio and properties like conjugation (Nishino et al., 2007). Cations of heavy metals complex with antibiotics such oxytetracycline (Palm et al., 2008), hence inhibiting their absorption in the intestines. With respect to animal health, environmental and food safety concerns for human consumption, it is critical to carefully manage the exposure of bacteria in animal wastewaters to heavy metals and to monitor the resultant impacts on the survival and establishment of indigenous flora and fauna. In this context, the present study was intended to assess the heavy metal resistance pattern among two groups of fecal pollution indicators; fecal streptococci (FS) and fecal coliforms and two pathogenic bacteria; Vibrio and Salmonella species isolated from sludge and wastewater samples from goat, sheep and cattle abattoirs in Nairobi, Kenya and to further investigate if there is a relationship between heavy metal and antibiotic resistance.

Salmonella species from the samples of wastewaters and sludge. Pigmentation of the colonies and Gram's staining followed by standard biochemical characterization such as motility, urease, $\mathrm{H}_{2} \mathrm{~S}$ production, glucose fermentation, indole, citrate utilization and the cytochrome oxidase tests, were used to confirm identity of the bacterial isolates (Mariita and Okemo, 2009). Assessment of metal toxicity: In order to quantitatively assess the effects of the heavy metals (HM) on bacterial isolates, plate diffusion and tube dilution methods were used (Konopka and Zakharova, 2000). The heavy metals tested were: $\mathrm{Cu}, \mathrm{Pb}, \mathrm{Hg}, \mathrm{Zn}$, $\mathrm{Co}$ and $\mathrm{Ni}$ that are commonly found in the environment. In the plate diffusion method, the percentage of bacterial resistance was calculated in terms of the ratio of the length of the growth in $\mathrm{mm}$ to the length of the total inoculated streak (Chari et al., 2011). Each isolate was also grown on nutrient agar medium without metals and used as control. The range of concentrations for heavy metals used was $5-300 \mathrm{mM}$. The highest concentration that completely inhibited growth of all studied bacterial was $300 \mathrm{mM}$, this concentration was decreased up to the lowest concentration in which there was $100 \%$ bacterial growth $(5 \mathrm{mM})$. Bacterial isolates that showed more than $50 \%$ growth in $25 \mathrm{mM}$ of each metal ion were considered to be resistant. 
Antibiotic sensitivity test: Sensitivity to antibiotics was determined by the agar diffusion technique recommended by the National Committee for Clinical Laboratory Standards (NCCLS, 2003) on MuellerHinton agar (Oxoid) using disks impregnated with : ampicillin $(25 \mu \mathrm{g})$; cotrimoxazole $(25 \mu \mathrm{g})$; streptomycin
$(10 \mu \mathrm{g})$; chloramphenicol $(30 \mu \mathrm{g})$; kanamycin $(30 \mu \mathrm{g})$; gentamycin $(10 \mu \mathrm{g})$; penicillin $\mathrm{G}(1 \mathrm{unit})$; methicillin $(5$ $\mu \mathrm{g})$; minocycline (30 $\mu \mathrm{g})$; lincomycin (2 $\mu \mathrm{g})$; erythromycin $(15 \mu \mathrm{g})$; tetracycline $(25 \mu \mathrm{g})$ and sulfamethoxazole $(200 \mu \mathrm{g})$.

\section{RESULTS}

Bacterial isolates obtained from samples:

Table 1: Bacterial strains isolated

\begin{tabular}{|c|c|c|}
\hline Strain no & Identification* & Origin \\
\hline S1 & Fecal coliform & Cattle wastewater, Kayole \\
\hline S2 & Fecal coliform & Cattle wastewater, Kayole \\
\hline S3 & Fecal coliform & Cattle sludge, Kayole \\
\hline S4 & Fecal coliform & Cattle sludge, Kayole \\
\hline S5 & Fecal coliform & Goat wastewaters, Kiamaiko \\
\hline S6 & Fecal coliform & Goat wastewaters, Kiamaiko \\
\hline S7 & Fecal coliform & Sheep wastewater, Kiamaiko \\
\hline S8 & Fecal coliform & Sheep wastewater, Kiamaiko \\
\hline S9 & Fecal coliform & Goat and sheep sludge, Kiamaiko \\
\hline S10 & Fecal coliform & Goat and sheep sludge, Kiamaiko \\
\hline S11 & Fecal Streptococci & Cattle wastewater, Kayole \\
\hline S12 & Fecal Streptococci & Cattle wastewater, Kayole \\
\hline S13 & Fecal Streptococci & Cattle sludge, Kayole \\
\hline S14 & Fecal Streptococci & Cattle sludge, Kayole \\
\hline S15 & Fecal Streptococci & Goat wastewaters, Kiamaiko \\
\hline S16 & Fecal Streptococci & Goat wastewaters, Kiamaiko \\
\hline S17 & Fecal Streptococci & Sheep wastewater, Kiamaiko \\
\hline S18 & Fecal Streptococci & Sheep wastewater, Kiamaiko \\
\hline S19 & Fecal Streptococci & Goat and sheep sludge, Kiamaiko \\
\hline S20 & Fecal Streptococci & Goat and sheep sludge, Kiamaiko \\
\hline S21 & Vibrio sp. & Cattle wastewater, Kayole \\
\hline $\mathrm{S} 22$ & Vibrio sp. & Cattle wastewater, Kayole \\
\hline S23 & Vibrio sp. & Cattle sludge, Kayole \\
\hline S24 & Vibrio sp. & Cattle sludge, Kayole \\
\hline S25 & Vibrio sp. & Goat wastewaters, Kiamaiko \\
\hline S26 & Vibrio sp. & Goat wastewaters, Kiamaiko \\
\hline S27 & Vibrio sp. & Sheep wastewater, Kiamaiko \\
\hline S28 & Vibrio sp. & Sheep wastewater, Kiamaiko \\
\hline S29 & Vibrio sp. & Goat and sheep sludge, Kiamaiko \\
\hline S30 & Vibrio sp. & Goat and sheep sludge, Kiamaiko \\
\hline S31 & Salmonella sp. & Cattle wastewater, Kayole \\
\hline S32 & Salmonella sp. & Cattle wastewater, Kayole \\
\hline S33 & Salmonella sp. & Cattle sludge, Kayole \\
\hline S34 & Salmonella sp. & Cattle sludge, Kayole \\
\hline S35 & Salmonella sp. & Goat wastewaters, Kiamaiko \\
\hline S36 & Salmonella sp. & Goat wastewaters, Kiamaiko \\
\hline S37 & Salmonella sp. & Sheep wastewater, Kiamaiko \\
\hline S38 & Salmonella sp. & Sheep wastewater, Kiamaiko \\
\hline S39 & Salmonella sp. & Goat and sheep sludge, Kiamaiko \\
\hline S40 & Salmonella sp. & Goat and sheep sludge, Kiamaiko \\
\hline
\end{tabular}


Isolates were identified by their morphology and biochemical properties.

A total of 40 bacterial isolates were obtained from the animal raw wastewaters and sludge from Kayole and Kiamaiko slaughterhouses in Nairobi. The isolates identified are indicated in Table 1.

Resistance of the bacterial isolates to heavy metals Resistance in solid media: Forty bacterial strains isolated from the samples of wastewaters and sludge were screened for heavy metal $(\mathrm{HM})$ resistance against six metals. Twenty seven (27) isolates showed resistance to multiple metal ions. However the patterns of resistance among these cultures varied (Table 2). From the 27 resistant strains, 5 (18.5\%) showed resistance to 5 different metal ions while only $1(3.7 \%)$ showed resistance to two different metal ions.

Table 2: Patterns of resistance of 27 bacterial isolates from abattoir wastewaters and sludge in Nairobi to 6 heavy metals on solid media

\begin{tabular}{c|ll}
\hline No. of resisted heavy metals & Patterns of resistance & No. (\%) of strains \\
\hline \multirow{2}{*}{5} & $\mathrm{Hg}, \mathrm{Cu}, \mathrm{Zn}, \mathrm{Pb}, \mathrm{Ni}$ & $2(7.4)$ \\
& $\mathrm{Co}, \mathrm{Cu}, \mathrm{Zn}, \mathrm{Pb}, \mathrm{Ni}$ & $3(11.1)$ \\
\cline { 2 - 3 } & $\mathrm{Co}, \mathrm{Cu}, \mathrm{Pb}, \mathrm{Ni}$ & $6(22.2)$ \\
& $\mathrm{Zn}, \mathrm{Cu}, \mathrm{Pb}, \mathrm{Ni}$ & $2(7.4)$ \\
& $\mathrm{Hg}, \mathrm{Zn}, \mathrm{Pb}, \mathrm{Ni}$ & $3(11.1)$ \\
& $\mathrm{Cu}, \mathrm{Co}, \mathrm{Zn}, \mathrm{Pb}$ & $1(3.7)$ \\
\cline { 2 - 3 } 3 & $\mathrm{Hg}, \mathrm{Pb}, \mathrm{Cu}$ & $1(3.7)$ \\
& $\mathrm{Zn}, \mathrm{Cu}, \mathrm{Ni}$ & $4(14.8)$ \\
& $\mathrm{Hg}, \mathrm{Zn}, \mathrm{Ni}$ & $2(7.4)$ \\
& $\mathrm{Pb}, \mathrm{Zn}, \mathrm{Ni}$ & $2(7.4)$ \\
\cline { 2 - 3 } 2 & $\mathrm{Hg}, \mathrm{Pb}$ & $1(3.7)$ \\
\hline
\end{tabular}

Overall, the order of toxicity of the metals was found to be $\mathrm{Hg}$ (more toxic) $>\mathrm{Co}>\mathrm{Cu}>\mathrm{Zn}>\mathrm{Pb}>\mathrm{Ni}$ (least toxic) (Figure 1). Resistance of the 27 bacterial isolates for each HM was as follows; $\mathrm{Hg} 9$ (33.3\%), Co 11 (40.7\%), Cu 18 (66.7\%), Zn 19 (70.4\%), Pb 21 (77.8\%) and $\mathrm{Ni}$
$24(88.9 \%)$. The toxic effect of the metals to the bacteria increased with increasing concentration. Nickel and Mercury were the most tolerated and the most toxic metals, respectively, while zinc, lead and copper gave intermediate results.

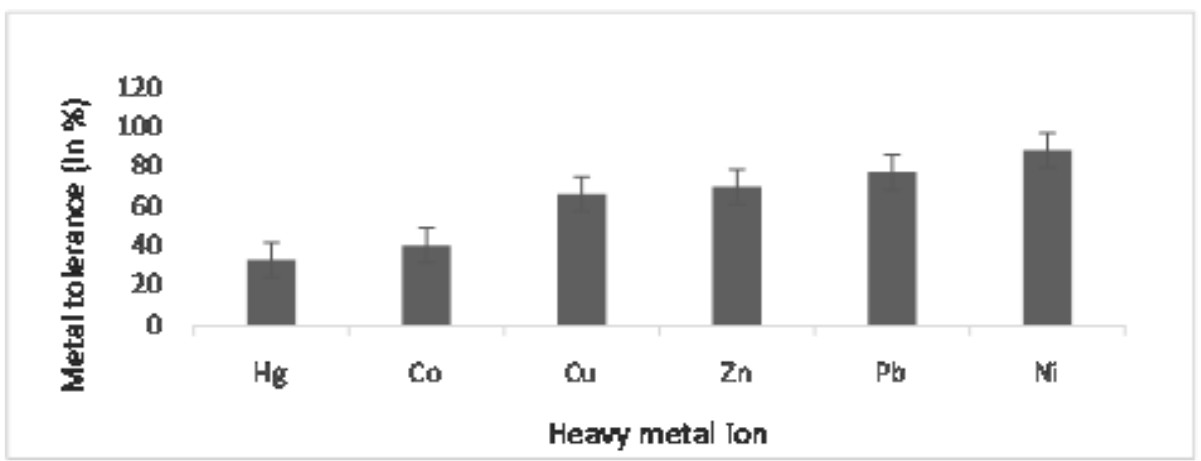

Figure 1: Tolerance of fecal coliforms, fecal streptococci, Vibrio and Salmonella species from abattoir wastewater and sludge in Nairobi to 6 different heavy metal ions.

Heavy metal toxicity in liquid media: All results obtained from experiments in liquid culture were expressed in minimal inhibitory concentration (MIC) (Table 3). All bacterial strains studied tolerated between $0.5-10 \mathrm{mM}$ of $\mathrm{Cu}$. The most tolerant species were essentially fecal coliform (S1, S7 and S8) and Vibrio
(S22) strain with an MIC of 10 . Tolerance was often below $5.0 \mathrm{mM}$ for Co, however, some strains (17.5\%) were inhibited at up to $10 \mathrm{mM}$ concentration of Co. Lead appeared less toxic, except for some bacterial strains that were found to be inhibited at lower concentration of $2.5 \mathrm{mM}$, such as fecal streptococci 
(S11 and S12), Salmonella (S39 and S40) and Vibrio species (S22). The highest tolerance was observed at 2.5 and $5.0 \mathrm{mM}$ concentration of $\mathrm{Zn}$. Some isolates $(30 \%)$ were inhibited at higher concentration of $10 \mathrm{mM}$ of zinc. Nickel appeared to be the most tolerated with quite a number of isolates inhibited at higher concentration of 10 and $15 \mathrm{mM}$. Mercury was the most toxic of all metals tested (average MIC $0.05 \mathrm{mM}$ ). Its action affected both Gram-positive and Gram-negative bacteria.

Table 3: Minimum Inhibitory Concentrations (MICs) of metal ions to bacterial isolates from abattoir wastewater and sludge in Nairobi.

\begin{tabular}{|c|c|c|c|c|c|c|c|}
\hline \multirow[t]{2}{*}{ Isolate } & \multirow[t]{2}{*}{ Identification } & \multicolumn{5}{|c|}{ MIC } & \multirow[b]{2}{*}{$\mathrm{Ni}$} \\
\hline & & $\mathrm{Cu}$ & Co & $\mathrm{Pb}$ & $\mathrm{Zn}$ & $\mathrm{Hg}$ & \\
\hline S1 & Fecal coliform & 10.0 & 1.0 & 10.0 & 2.5 & 0.001 & 2.5 \\
\hline S2 & Fecal coliform & 2.5 & 10.0 & 15.0 & 5.0 & 0.05 & 10.0 \\
\hline S3 & Fecal coliform & 1.0 & 10.0 & 15.0 & 5.0 & 0.1 & 10.0 \\
\hline S4 & Fecal coliform & 2.5 & 2.5 & 15.0 & 2.5 & 0.05 & 2.5 \\
\hline S5 & Fecal coliform & 2.5 & 1.0 & 10.0 & 2.5 & 0.05 & 15.0 \\
\hline S6 & Fecal coliform & 0.5 & 1.0 & 10.0 & 2.5 & 1.0 & 15.0 \\
\hline S7 & Fecal coliform & 10.0 & 2.5 & 5.0 & 2.5 & 0.005 & 0.5 \\
\hline S8 & Fecal coliform & 10.0 & 2.5 & 15.0 & 5.0 & 0.5 & 5.0 \\
\hline S9 & Fecal coliform & 1.0 & 1.0 & 5.0 & 10.0 & 1.0 & 5.0 \\
\hline S10 & Fecal coliform & 1.5 & 2.5 & 15.0 & 5.0 & 0.05 & 10.0 \\
\hline S11 & Fecal streptococci & 1.0 & 5.0 & 2.5 & 10.0 & 0.05 & 5.0 \\
\hline S12 & Fecal streptococci & 1.0 & 5.0 & 2.5 & 10.0 & 0.05 & 10.0 \\
\hline $\mathrm{S} 13$ & Fecal streptococci & 2.5 & 10.0 & 15.0 & 5.0 & 0.01 & 15.0 \\
\hline S14 & Fecal streptococci & 1.5 & 5.0 & 5.0 & 10.0 & 0.05 & 15.0 \\
\hline S15 & Fecal streptococci & 1.0 & 10.0 & 15.0 & 2.5 & 0.1 & 10.0 \\
\hline S16 & Fecal streptococci & 0.5 & 2.5 & 15.0 & 5.0 & 0.1 & 15.0 \\
\hline S17 & Fecal streptococci & 0.5 & 1.0 & 10.0 & 5.0 & 0.05 & 15.0 \\
\hline S18 & Fecal streptococci & 2.5 & 1.0 & 10.0 & 5.0 & 0.05 & 10.0 \\
\hline$S 19 / 20$ & Fecal streptococci & 2.5 & 1.0 & 15.0 & 2.5 & 0.5 & 10.0 \\
\hline S21 & Vibrio spp & 1.0 & 10.0 & 5.0 & 5.0 & 0.05 & 15.0 \\
\hline S22 & Vibrio spp & 10.0 & 2.5 & 2.5 & 5.0 & 0.005 & 2.5 \\
\hline S23 & Vibrio spp & 2.5 & 1.0 & 5.0 & 10.0 & 0.1 & 15.0 \\
\hline S24 & Vibrio spp & 2.5 & 1.0 & 5.0 & 10.0 & 0.1 & 15.0 \\
\hline S25 & Vibrio spp & 1.0 & 2.5 & 15.0 & 2.5 & 0.01 & 15.0 \\
\hline S26 & Vibrio spp & 1.0 & 2.5 & 10.0 & 2.5 & 0.05 & 2.5 \\
\hline S27 & Vibrio spp & 1.0 & 2.5 & 10.0 & 2.5 & 0.005 & 2.5 \\
\hline S28 & Vibrio spp & 5.0 & 5.0 & 10.0 & 2.5 & 0.1 & 15.0 \\
\hline S29 & Vibrio spp & 5.0 & 15.0 & 10.0 & 10.0 & 1.0 & 5.0 \\
\hline S30 & Vibrio spp & 5.0 & 2.5 & 5.0 & 2.5 & 0.05 & 10.0 \\
\hline S31 & Salmonella spp & 1.0 & 2.5 & 15.0 & 5.0 & 0.05 & 15.0 \\
\hline S32 & Salmonella spp & 1.0 & 5.0 & 15.0 & 10.0 & 1.0 & 10.0 \\
\hline S33 & Salmonella spp & 2.5 & 1.0 & 10.0 & 10.0 & 1.0 & 10.0 \\
\hline S34 & Salmonella spp & 1.0 & 2.5 & 10.0 & 10.0 & 0.05 & 15.0 \\
\hline S35 & Salmonella spp & 2.5 & 10.0 & 10.0 & 5.0 & 0.05 & 15.0 \\
\hline S36 & Salmonella spp & 2.5 & 10.0 & 10.0 & 5.0 & 0.05 & 15.0 \\
\hline S37 & Salmonella spp & 1.5 & 1.0 & 10.0 & 2.5 & 0.05 & 2.5 \\
\hline S38 & Salmonella spp & 1.0 & 1.0 & 5.0 & 2.5 & 0.05 & 15.0 \\
\hline S39 & Salmonella spp & 1.0 & 5.0 & 2.5 & 10.0 & 0.05 & 15.0 \\
\hline
\end{tabular}


Interaction of metal resistance and antibiotic resistance: In this study, all the metal resistant isolates also showed resistance to different and multiple antibiotics (Table 4). With all six of the metals tested, there was a tendency towards a high frequency of resistance to lincomycin (77.8\%), tetracycline (70.4\%) and ampicillin $(66.7 \%)$ among all the isolates. Among the bacterial isolates, multiple metal tolerance was shown in $29.6 \%$
(8) of fecal coliforms and fecal streptococci, 18.5\% (5) of Vibrio species and $22.2 \%$ (6) of Salmonella species. An equal number of heavy metal resistant bacteria isolates, $6(22.2 \%)$, had been isolated from goat and sheep sludge, cattle, goat and sheep wastewater samples while only $3(11.1 \%)$ were isolated from the cattle sludge samples.

Table 4: Heavy metal resistance pattern of fecal coliforms, fecal streptococci, Salmonella and Vibrio isolated from wastewaters and sludge in abattoirs around Nairobi.

\begin{tabular}{|c|c|c|c|}
\hline Strain & Identification & HM resistance pattern & AR pattern \\
\hline S1 & Fecal coliform & $\mathrm{Hg}, \mathrm{Cu}, \mathrm{Zn}, \mathrm{Pb}, \mathrm{Ni}$ & Tet, sulf, pen, ery, kan, gen,cot, chlo \\
\hline S2 & Fecal coliform & $\mathrm{Cu}, \mathrm{Pb}, \mathrm{Ni}, \mathrm{Co}$ & Linc, sulf, strep, cot, mino, chlo \\
\hline S5 & Fecal coliform & $\mathrm{Hg}, \mathrm{Pb}, \mathrm{Cu}$ & Linc, amp, met, tet, sulf, ery, mino \\
\hline S6 & Fecal coliform & $\mathrm{Cu}, \mathrm{Zn}, \mathrm{Ni}$ & Tet, kan, gen, strep \\
\hline S7 & Fecal coliform & $\mathrm{Zn}, \mathrm{Cu}, \mathrm{Pb}, \mathrm{Ni}$ & Linc, amp, met, tet, sulf, ery, mino \\
\hline S8 & Fecal coliform & $\mathrm{Cu}, \mathrm{Pb}, \mathrm{Ni}, \mathrm{Co}$ & Linc, amp, met, tet, sulf, ery, mino \\
\hline S9 & Fecal coliform & $\mathrm{Hg}, \mathrm{Zn}, \mathrm{Ni}$ & Linc, amp, met, tet, ery, pen, gen \\
\hline S10 & Fecal coliform & $\mathrm{Cu}, \mathrm{Zn}, \mathrm{Ni}$ & Linc, sulf, strep, cot, mino, chlo \\
\hline S11 & Fecal streptococci & $\mathrm{Cu}, \mathrm{Zn}, \mathrm{Pb}, \mathrm{Co}$ & Linc, amp, met, tet, ery, pen, gen \\
\hline S12 & Fecal streptococci & $\mathrm{Zn}, \mathrm{Cu}, \mathrm{Ni}$ & Linc, amp, met, sulf, pen, kan \\
\hline S13 & Fecal streptococci & $\mathrm{Hg}, \mathrm{Cu}, \mathrm{Pb}, \mathrm{Zn}, \mathrm{Ni}$ & Tet, sulf, pen, ery, kan, gen,cot, chlo \\
\hline
\end{tabular}


Nyamboya et al. J. Appl. Biosci. 2013. Heavy metal and antibiotic resistance of fecal pathogens from wastewaters of abattoirs in Nairobi

\begin{tabular}{|c|c|c|c|}
\hline S15 & Fecal streptococci & $\mathrm{Hg}, \mathrm{Zn}, \mathrm{Ni}$ & Tet, sulf, pen, ery, kan, gen,cot, chlo \\
\hline S16 & Fecal streptococci & $\mathrm{Hg}, \mathrm{Zn}, \mathrm{Ni}, \mathrm{Pb}$ & Tet, sulf, pen, ery, kan, gen,cot, chlo \\
\hline S18 & Fecal streptococci & $\mathrm{Cu}, \mathrm{Zn}, \mathrm{Ni}$ & Linc, amp, tet, kan, strep, cot \\
\hline S19 & Fecal streptococci & $\mathrm{Cu}, \mathrm{Co}, \mathrm{Pb}, \mathrm{Ni}$ & Linc, sulf, strep, cot, mino, chlo \\
\hline S20 & Fecal streptococci & $\mathrm{Cu}, \mathrm{Co}, \mathrm{Pb}, \mathrm{Ni}$ & Linc, sulf, strep, cot, mino, chlo \\
\hline S21 & Vibrio spp & $\mathrm{Hg}, \mathrm{Ni}, \mathrm{Pb}, \mathrm{Zn}$ & Linc, amp, met, tet, ery, pen, gen \\
\hline S25 & Vibrio spp & $\mathrm{Zn}, \mathrm{Ni}, \mathrm{Pb}$ & Linc, amp, met, tet, ery, pen, gen \\
\hline S27 & Vibrio spp & $\mathrm{Cu}, \mathrm{Ni}, \mathrm{Co}, \mathrm{Pb}, \mathrm{Zn}$ & Linc, amp, met, tet, ery, pen, gen \\
\hline S28 & Vibrio spp & $\mathrm{Hg}, \mathrm{Pb}$ & Linc, amp, met, tet, sulf, ery, mino \\
\hline S30 & Vibrio spp & $\mathrm{Zn}, \mathrm{Ni}, \mathrm{Pb}$ & Amp, met, ery, chlo, strep, cot \\
\hline S31 & Salmonella spp & $\mathrm{Co}, \mathrm{Cu}, \mathrm{Ni}, \mathrm{Pb}$ & Linc, amp, met, sulf, pen, kan \\
\hline S33 & Salmonella spp & $\mathrm{Co}, \mathrm{Pb}, \mathrm{Zn}, \mathrm{Ni}, \mathrm{Cu}$ & Linc, amp, met, tet, sulf, ery, mino \\
\hline S34 & Salmonella spp & $\mathrm{Hg}, \mathrm{Ni}, \mathrm{Zn}, \mathrm{Pb}$ & Linc, amp, tet, kan, strep, cot \\
\hline S35 & Salmonella spp & $\mathrm{Cu}, \mathrm{Pb}, \mathrm{Ni}, \mathrm{Zn}$ & Linc, amp, met, tet, ery, pen, gen \\
\hline S37 & Salmonella spp & $\mathrm{Cu}, \mathrm{Co}, \mathrm{Pb}, \mathrm{Ni}$ & Linc, amp, met, sulf, pen, kan \\
\hline S40 & Salmonella spp & $\mathrm{Cu}, \mathrm{Co}, \mathrm{Pb}, \mathrm{Ni}, \mathrm{Zn}$ & Linc, amp, tet, kan, strep, cot \\
\hline
\end{tabular}

Key: Amp- ampicillin, Linc-lincomycin, Pen-penicillin, Met-methicillin, Ery-erythromycin, Tet -tetracycline, Cot-cotrimoxazole, Strep-streptomycin, Kan-kanamycin, Gen-gentamicin, Sulf-sulfamethoxazole, Chlo-chloramphenicol and Mino-minocycline 


\section{DISCUSSION}

This study highlights the prevalence of metal resistant microbial populations in raw animal wastewaters and sludge. The microbial growth decreased with the increase in concentration of heavy metals indicating toxic effect of the heavy metals on the growth of microorganisms. The heavy metal tolerance of isolated bacteria was heterogeneous. This difference in response of isolates could be due to the selectivity of microbial culture techniques employed especially with regard to the nature and specificity of growth media. The tests carried out in liquid media were active at much lower concentrations than in solid media, possibly because in liquid media, the metal is in solution hence contact with microorganisms is more efficient and it is easier for bacterial isolates to take up nutrients. Irrespective of the origin of bacteria, $\mathrm{Hg}$ appeared to be the most toxic and hence could be expected to significantly impact on animal microbial flora (Kumar and Kayatsha, 2009). Several bacterial species have been shown to develop resistance to mercury and other HM (Singh et al., 2008; Parisa et al., 2011). The higher $\mathrm{Hg}$ sensitivity could be as a result of the ions reaction with the thiol groups of cysteine residues of the enzymes leading to formation of mercaptides (Zaborskaet al., 2004). The presence of metallothionein-like proteins in the system of bacteria that exhibit tolerance to $\mathrm{HM}$ such as $\mathrm{Hg}, \mathrm{Cd}, \mathrm{Zn}, \mathrm{Ni}$, and $\mathrm{Co}$ has been reported (Robinson et al., 2001). Microorganisms are also known to possess a high metal affinity and can accumulate heavy metals by various mechanisms (Rehman et al., 2008). In this study, the resistant profiles differed among animal species. For bacterial species from sheep waste, the sensitivity trend was in the order: $\mathrm{Hg}>\mathrm{Co}>\mathrm{Cu}>\mathrm{Zn}>$ $\mathrm{Ni}>\mathrm{Pb}$, similar to that of goat but somewhat different from that of cattle (i.e., $\mathrm{Hg}>\mathrm{Cu}>\mathrm{Co}>\mathrm{Zn}>\mathrm{Pb}>\mathrm{Ni}$ ). The difference in toxicity order could be due to several factors including bioavailability, chemical form, conditions of metabolic activity and other bacterial species related factors (Yue et al., 2007). Since HM share similarities in their toxicity mechanisms, multiple

\section{ACKNOWLEDGEMENT}

We thank Kenyatta University offering laboratory space; Dr. C. Makori of the Department of Veterinary Services, Kenya, for facilitating ethical clearance process and workers of Kayole and Kiamaiko abattoirs in Nairobi for tolerance is common phenomena among HM resistant bacteria. In this study some of the 27 bacterial isolates showed multiple resistance to the studied metal ions. This observation supports the idea that metal resistance could be interrelated among different metal ions (Amalesh et al., 2012). Among the 27 metal resistant bacteria isolates, multiple metal tolerance was shown in $29.6 \%$ (8) of fecal coliforms and fecal streptococci, $18.5 \%$ (5) of Vibrio species and $22.2 \%$ (6) of Salmonella species. Metal resistance may be related to the products of capsular polysaccharides often present in the Enterobacter group of organisms which are able to combine with metals to protect themselves from metal toxicity (Adarsh et al., 2007). More often, the resistance is plasmid -borne and transferrable in nature leading to its spread among the sensitive aquatic bacteria including coliforms. The 27 multiple metal resistant isolates had been isolated from the cattle, goat and sheep abattoirs in different numbers. This indicates that there could be a build-up in all the three studied abattoirs leading to an existing pool of genes with HM resistance. No particular metal resistance pattern was predictive of a particular pattern of antibiotic resistance and all the metal resistant isolates were also resistant to various antibiotics. This suggests that HM contamination of these animal wastewaters could be inducing multidrug resistance as earlier suggested by Palm et al., (2008). Observations made with respect to metal-antibiotic-double resistance were also reported by Berg et al., 2010. For instance, copper tolerant bacteria were more frequently resistant to antibiotics (ampicillin, sulfonamides and chloramphenicol) than copper sensitive strains. High incidence of metal-antibiotic-double tolerance for penicillin and copper, ampicillin and nickel, lead and many antibiotics including $\beta$-lactams was observed in this study and has also been reported by Christina et al. (2012). These results show that the combined expression of antibiotic and heavy metal resistance may not be a chance phenomenon but rather a result of selection by $\mathrm{HM}$ presence in an environment.

assistance in the collection of samples and Mr. D. Ng'ang'a of Plant and Microbial Science laboratory, Kenyatta University, for technical assistance. 


\section{REFERENCES}

Adarsh VK, Madhusmita M, Sanhita C, Sudarshan M, Thakur AR, Chaudhuri SR, 2007. Studies on metal microbe interaction of three bacterial isolates from East Calcutta Wetland. Online Journal of Biological Sciences. 7(2): 80-88.

Akinbowale OL, Peng H, Grant P, Barton MD, 2007. Antibiotic and heavy metal resistance in motile aeromonads and Pseudomonads from rainbow trout (Oncorhynchus mykiss) farms in Australia. International Journal of Antimicrobial Agents 30: 177-82.

Amalesh S, Paramita B, Mahamuda K, Chandrima S, Pinaki P, Anarup M, 2012. An investigation on heavy metal tolerance and antibiotic resistance properties of bacterial strain Bacillus sp. isolated from municipal waste. Journal of Microbiology and Biotechnology Research 2(2): 178-189.

Berg J, Thorsen MK, Holm PE, Jensen J, Nybroe O, Brandt KK, 2010. Cu exposure under field conditions co-selects for antibiotic resistance as determined by a novel cultivationindependent bacterial community tolerance assay. Environmental Science of Technology 44: 8724-8728.

Chari N, Balasubramanian G, Shunmugiah KP, 2011. Assessment and characterization of heavy metal resistance in Palk Bay sediment bacteria. Marine Environment Research 71: 283-294.

Christina SH, Christa M, Katrin SM, Sabin M, Stefanie S, Kurin S, Johann B, 2012. Heavy metals in liquid pig manure in light of bacterial antimicrobial resistance. Environmental Research 113: 21-27.

Konopka, A. and Zakharova, 2000. Quantification of bacterial lead resistance via activity assays. Journal of Microbial methods 37: 17-22.

Kumar S. and Kayastha AM, 2009. Inhibition studies of soybean (Glycine max) urease with heavy metals, sodium salts of mineral acids, boric acid, and boronic acids. Journal of Enzyme Inhibition and Medicinal Chemistry 1: 1-7.

Lopez-Maury L, Garcia-Dominguez M, Florencio FJ, Reyes JC, 2002.A two component signal transduction system involved in nickel sensing in the Cyanobacterium synechocystis sp. PCC 6803. Molecular Microbiology 43: 247-56.

Mariita MR. and Okemo OP, 2009. Usefulness of fecal streptococci as indicator of presence of
Salmonella spp. and Vibrio cholerae in sewage effluents. Journal of Microbiology 5(1): 19-24.

National Committee for Clinical Laboratory Standards (2003).Performance Standards for Antimicrobial Susceptibility Testing, NCCLS M100-S14, 14 ${ }^{\text {th }}$ edition. National Committee for Clinical Laboratory Standards, Wayne, PA.

Nishino K, Nikaido E, Yamaguchi A, 2007. Regulation of multidrug efflux systems involved in multidrug and metal resistance of Salmonella enteric serovar Typhimurium. Journal of Bacteriology 189: 9066-9075.

Palm GJ, Lederer T, Orth P, Saenger W, Takahashi M, Hillen W, Hinrichs W, 2008. Specific binding of divalent metal ions to tetracycline and to the Tet repressor/tetracycline complex. Journal of Biology and Inorganic Chemistry 13: 10971110.

Parisa K, Mehran H, Arezoo T, 2011. Multimetal resistance study of bacteria high resistance to mercury isolated from dental clinic effluent. African Journal of Microbiological Research 5(7): 831-837.

Rehman A, Shakoori FR, Shakoori AR, 2008. Uptake of heavy metals by Stylonychia mytilus and its possible use in decontamination of industrial wastewater. World Journal of Microbiology and Biotechnology 24: 47-53.

Robinson NJ, Whitehall SK, Cavet, JS, 2001. Microbial metallothioneins. Advances in Microbial Physiology 44: 183-213.

Singh S, Hyun KS, Mulchandani A, Chen W, 2008. Bioremediation: Environmental clean up through pathway engineering. Current Opinion in Biotechnology 19: 437-444.

Wenzel RP. and Edmond MB, 2009. Managing antibiotic resistance. Journal of Medicine343: 1961-1963.

Yue ZB, Yu HQ, Wang ZL, 2007. Anaerobic digestion of cattail with rumen culture in the presence of heavy metals. Bioresource Technology 98: 781-786.

Zaborska W, Krajewska B, Olech Z, 2004. Heavy metal ions inhibition of jack bean urease: potential for rapid contaminant probing. Journal of Enzyme Inhibition and Medicinal Chemistry 19: 65-69. 
